\title{
Improvement of blood glucose control in IDDM patients retards the progression of morphological changes in early diabetic nephropathy
}

\author{
H.-J. Bangstad ${ }^{1}$, R. Østerby ${ }^{2}$, K. Dahl-Jørgensen ${ }^{1}$, K.J. Berg ${ }^{3}$, A.Hartmann ${ }^{3}$, K. F. Hanssen ${ }^{1}$ \\ ${ }^{1}$ Aker Diabetes Research Centre, Aker University Hospital, Oslo, Norway \\ ${ }^{2}$ Institute of Experimental Clinical Research, Kommunehospitalet, Århus, Denmark \\ ${ }^{3}$ Nephrological Section, Medical Department B, Rikshospitalet, Oslo, Norway
}

Summary We investigated in a randomized, prospective study the influence of improved blood glucose control during 2-3 years in young insulin-dependent diabetic (IDDM) patients with microalbuminuria, which is indicative of early nephropathy. Patients were randomized either to intensive treatment by continuous subcutaneous insulin infusion (CSII) $(n=9)$ or CT $(n=9)$. Kidney biopsies were taken at baseline and after 26-34 months. End points were structural changes in the glomeruli. Sensitive, quantitative, morphometric methods were used. The blood glucose control improved significantly $(p=0.01)$ during the study in the CSII-group as glycated haemoglobin $\left(\mathrm{HbA}_{1 \mathrm{c}}\right)$ fell from $10.1 \%$ ([95\% CI] 8.9-11.3) to 8.6\% (7.9-9.2), but not in the CT-group, $10.1 \%(8.3-11.9)$ vs $9.7 \%$ (8.7-10.8). Mean $\mathrm{HbA}_{1 \mathrm{c}}$ during the study period was significantly lower in the CSII-group than in the CTgroup, $8.7 \%(8.1-9.3)$ vs $9.9 \%(8.5-11.3), p=0.04$. Basement membrane thickness (BMT) increased in both groups, most (CT vs CSII, $p=0.03$ ) in the CT- group: $140 \mathrm{~nm}$ (50-230) vs CSII: $56 \mathrm{~nm}(27-86)$. In the CT-group only an increase was seen in matrix/mesangial volume fraction $(p=0.006)$ and matrix star volume $(p=0.04)$. Furthermore, a positive correlation between mean $\mathrm{HbA}_{1 \mathrm{c}}$ during the study and change from baseline in BMT $(r=0.70, p=0.001)$ and matrix/glomerular volume fraction $(r=0.33, p=0.09, \mathrm{NS})$ was demonstrated. Albumin excretion rate correlated significantly to BMT and most of the matrix parameters. The present study shows that during a period of only 2.5 years, a close relationship between the level of mean blood glucose and progression of glomerular morphological changes in early diabetic nephropathy can be demonstrated. [Diabetologia (1994) 37: 483490]

Key words Diabetic glomerulopathy, microalbuminuria, basement membrane thickness, mesangial expansion, mesangial matrix, stereology, hyperglycaemia.
Even though hyperglycaemia is a prerequisite for the development of diabetic nephropathy, the impact of long-term hyperglycaemia on the progression of early diabetic nephropathy is not well understood. In 1978

Received: 24 August 1993

and in revised form: 23 November 1993

Corresponding author: Dr. H.-J. Bangstad, Aker Diabetes Research Centre, Aker University Hospital, N-0514 Oslo, Norway

Abbreviations: IDDM, insulin-dependent diabetes mellitus; CSII, continuous subcutaneous insulin infusion; CT, conventional treatment (2,3 or multiple injections daily); BMT, basement membrane thickness; AER, urinary albumin excretion rate; $\mathrm{CI}$, confidence interval.
Pirart [1] showed in a study comprising both IDDM and NIDDM patients, that the risk of development of serious complications including nephropathy, is associated with more severe hyperglycaemia. In cross-sectional $[2-6]$ and long-term retrospective studies $[7,8]$ an association between the level of glycated haemoglobin and microalbuminuria, which is an early sign of diabetic nephropathy $[9,10]$, has been found. Improved blood glucose control obtained in prospective randomized studies has retarded the progression of AER [11] and the risk of developing clinical nephropathy $[12,13]$. However, it is not known if reducing mean blood glucose affects the progression of morphological changes at a very early stage of diabetic nephropathy. Therefore we tested in a randomized, prospec- 
tive intervention study the hypothesis that the progression rate of characteristic morphological changes in early diabetic nephropathy is related to mean blood glucose level.

\section{Subjects, materials and methods}

\section{Subjects}

The initial study comprised 371 IDDM patients between 1030 years of age with diabetes duration of more than 5 years who were screened for persistent microalbuminuria. The patients were non-proteinuric as demonstrated by a negative Albustix (Boehringer Mannheim GmbH Mannheim, Germany) and came from five different out-patient clinics (282 subjects from Aker University Hospital, Paediatric and Medical Departments, and 98 from local Paediatric Departments). Persistent microalbuminuria was defined as an AER between $15-200 \mu \mathrm{g} / \mathrm{min}$ in at least two out of three overnight urine samples taken during 1 year. The lower AER-limit of $15 \mu \mathrm{g} / \mathrm{min}$, rather than the conventional $20 \mu \mathrm{g} / \mathrm{min}$, was chosen since we used overnight urine samples. The AER is reduced by $25 \%$ during the night compared to 24-h samples [14]. We invited the 45 patients $(12 \%)$, who satisfied this criterion, to take part in a prospective 2-year trial, of whom 33 patients agreed. This paper describes the $18 \mathrm{pa}-$ tients who were above 18 years of age in whom renal biopsy could be performed. Each of the patients received thorough information and gave their written consent. The protocol was approved by the Regional Ethics Committee. No serious complication of the kidney procedure was observed. One patient had macroscopic haematuria for 1 day without any other signs.

The patients were then randomly assigned to CSII by a portable pump or CT (multiple injections or two-three injections per day). Before the study 27 of the patients were on multiple injections, three, on two daily injections and three, on three daily injections. The randomization was carried out by a computer program in the following priority in order to make the best possible distribution of basic characteristics: mean 1-year prestudy $\mathrm{HbA}_{1 \mathrm{c}}$, duration of diabetes, median 1-year pre-study AER, age and sex. The statistician doing this had no knowledge of the patients identification or mode of treatment.

Three patients were excluded from the controlled, prospective study. The reasons were incidence of alcohol abuse, atopic eczema, and problems with the fixation of the subcutaneous needle, respectively, making pump treatment inconvenient.

The characteristics of the 18 patients who completed the 2year study, are shown in Table 1. The patients did not have proliferative retinopathy and all but one patient had blood pressure less than $140 / 90 \mathrm{~mm} \mathrm{Hg}$. This patient was initially hypertensive $(150 / 98 \mathrm{~mm} \mathrm{Hg})$, but the blood pressure declined to $145 / 85 \mathrm{~mm}$ Hg in the course of 6 months without antihypertensive treatment.

The patients were followed regularly by the same investigator (HJB) at the out-patient clinic at 2-month intervals. Renal function tests and biopsies were performed at entry and after 2634 months also in the three patients who were excluded from the randomized study.

\section{Methods}

AER was measured in at least two timed overnight urine samples in the year preceding the study, and then at 2-month intervals. The albumin concentration was measured by immunoturbidimetry in samples kept at $4^{\circ} \mathrm{C}$ from 1 to 3 days. The inter-
Table 1. Individual clinical data at entry from 18 IDDM subjects on CSII or CT

\begin{tabular}{|c|c|c|c|c|c|c|}
\hline \multirow[t]{2}{*}{$\begin{array}{l}\text { Subject } \\
\text { no }\end{array}$} & \multirow[t]{2}{*}{$\begin{array}{l}\text { Age } \\
\text { (years) }\end{array}$} & \multirow{2}{*}{$\begin{array}{l}\text { Dura- } \\
\text { tion } \\
\text { (years) }\end{array}$} & \multirow{2}{*}{$\begin{array}{l}\text { AER } \\
(\mu \mathrm{g} / \mathrm{min}\end{array}$} & \multirow[t]{2}{*}{$\begin{array}{l}\mathrm{HbA}_{1 \mathrm{r}} \\
(\%)\end{array}$} & \multicolumn{2}{|c|}{$\begin{array}{l}\text { Blood pressure } \\
(\mathrm{mm} \mathrm{Hg})\end{array}$} \\
\hline & & & & & Systolic & Diastolic \\
\hline \multicolumn{7}{|l|}{ CSII: } \\
\hline 1 & 18 & 10 & 15 & 10.3 & 110 & 85 \\
\hline 2 & 21 & 9 & 59 & 9.1 & 115 & 78 \\
\hline 3 & 18 & 12 & 19 & 13.7 & 110 & 78 \\
\hline 4 & 23 & 18 & 16 & 8.8 & 137 & 67 \\
\hline 5 & 18 & 7 & 25 & 10.1 & 134 & 78 \\
\hline 6 & 29 & 15 & 40 & 8.4 & 138 & 78 \\
\hline 7 & 18 & 11 & 30 & 10.7 & 118 & 80 \\
\hline 8 & 19 & 10 & 18 & 9.8 & 114 & 69 \\
\hline 9 & 19 & 12 & 131 & 10.3 & 134 & 90 \\
\hline Mean & 20.3 & 11.6 & 39 & 10.1 & 123 & 78 \\
\hline $95 \% \mathrm{CI}$ & $17-23$ & $9-14$ & $11-68$ & $8.9-11.3$ & $114-133$ & $73-84$ \\
\hline \multicolumn{7}{|c|}{$C T:$} \\
\hline 10 & 19 & 10 & 33 & 12.5 & 145 & 88 \\
\hline 11 & 19 & 12 & 30 & 8.6 & 135 & 90 \\
\hline 12 & 18 & 12 & 194 & 13.8 & 120 & 80 \\
\hline 13 & 20 & 8 & 40 & 10.7 & 125 & 85 \\
\hline 14 & 18 & 13 & 50 & 12.5 & 118 & 76 \\
\hline 15 & 18 & 12 & 32 & 9.1 & 118 & 78 \\
\hline 16 & 19 & 10 & 37 & 7.8 & 150 & 98 \\
\hline 17 & 19 & 12 & 18 & 8.0 & 120 & 75 \\
\hline 18 & 29 & 12 & 27 & 7.9 & 115 & 85 \\
\hline Mean & 19.9 & 11.2 & 51 & 10.1 & 127 & 84 \\
\hline $95 \%$ CI & $17-23$ & $10-12$ & $10-93$ & $8.3-11.9$ & $117-137$ & $78-90$ \\
\hline
\end{tabular}

${ }^{a}$ Mean values of $2-4$ measurement in the year preceding the study

assay coefficient of variation was $4.7 \%$ in the range of 10 $50 \mathrm{mg} / \mathrm{l}$. The urine samples were negative for leucocytes, nitrite, albumin and ketones as demonstrated by Nephur-Test Leuco (Boehringer-Mannheim $\mathrm{GmbH}$ ).

$\mathrm{HbA}_{1 \mathrm{c}}$ was analysed with an HPLC method ("Diamat" analyzer; Biorad, Richmond, Calif., USA). Normal range was 4.3$6.1 \%$, with an inter-assay coefficient of variation of $3 \%$.

Blood pressure was measured by conventional mercury sphygmomanometer with patients sitting after a 10-min rest, and diastolic pressure was recorded at the disappearance of the Korotkoff's V sound.

Glomerular filtration rate was measured by inulin-clearance (Inulin; Laevosan, Linz, Austria) after oral water loading. High concentrations of interfering glucose were removed by glucose oxidase. Glomerular filtration rate was standardized to a body surface area of $1.73 \mathrm{~m}^{2}$.

The renal charge selectivity index was measured as the ratio between the urinary clearances of two endogenous molecules, $\mathrm{IgG}$ and $\mathrm{IgG}_{4}$ as previously described [15]. These molecules have the same size and configuration, but $\mathrm{IgG}_{4}$ is more anionic than total-IgG, the isoelectric points $=5.5-6.0$ vs $5.8-7.3$, respectively [16].

\section{Renal biopsies}

In the diabetic patients ultrasound guided kidney biopsies were taken with an 18 gauge needle integrated automatic gun-biopsy system (Biopty, Bard Inc, Covington, Ga., USA). The tissue was 


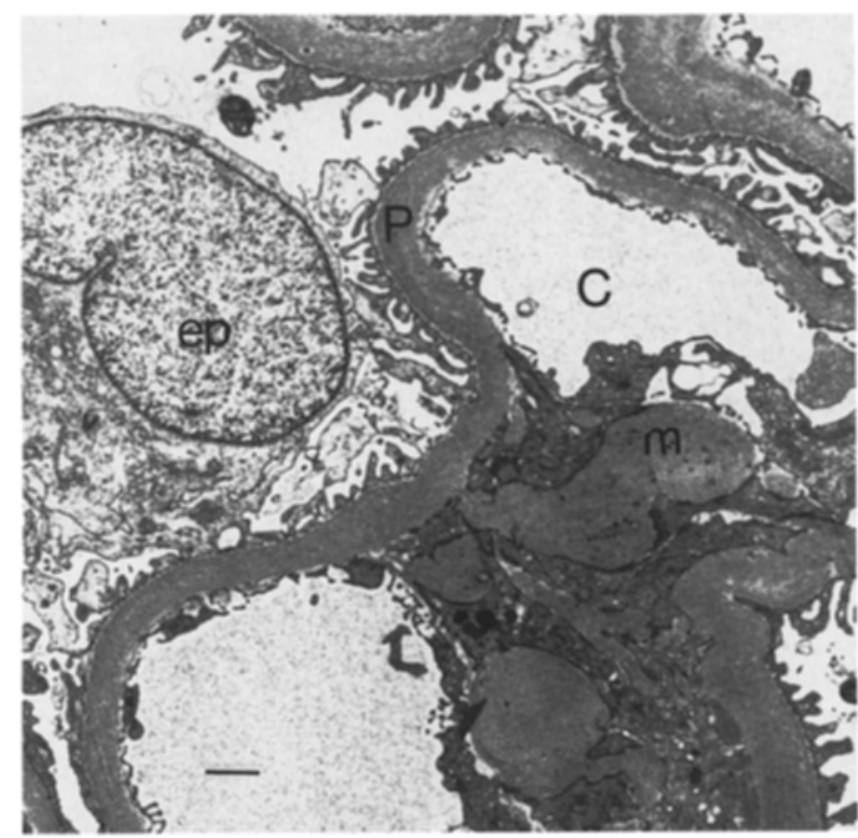

Fig. 1. Section of glomerular tuft. The separation between the peripheral basement membrane ( $p)$ and the mesangial matrix $(\mathrm{m})$ is indicated. Epithelial cell: ep; capillary space: $c$. The bar equals $1 \mu \mathrm{m}$

immediately immersed into the fixative, a $2 \%$ glutaraldehyde solution in modified Tyrode buffer and mailed in the fixative to the laboratory in Århus. Embedding into Vestopal was done after 3-10 days storage in the fixative. The investigator (R $\varnothing)$ was not aware of the group designation of the subjects.

\section{Measurement of structural parameters}

The methods for obtaining quantitative structural parameters in the glomerulus have been described recently [10]. Three glomeruli from each biopsy were sampled independently of size and structure, except for one biopsy in which only two glomeruli were obtained. The structures in question are peripheral basement membrane, the mesangial region and the mesangial matrix.

Photomontages of the entire glomerular profile were made at a magnification of $2350 \times$ at three levels in each glomerulus. The set of three sections, separated by $60 \mu \mathrm{m}$, had a random position along the glomerular diameter, and was used for the estimate of mesangial volume fraction and surface densities of the peripheral $\mathrm{BM}$, mesangial-urinary and the mesangial-capillary surfaces. A systematic subsample of the largest of the three sections was photographed at $9900 \times$ magnification and was used for measurements of BM thickness and mesangial matrix.

Thickness of the peripheral basement membrane (BMT): the delineation between peripheral BM and the mesangial matrix was defined as illustrated in Figure 1. Measuring points were sampled independently of the BM appearance with a line grid, measurements taken at intersections between grid lines and the endothelial-BM interface. The 'true BM thickness' was estimated [17], classifying only at the sampling places, where the distinctness of the epithelial cell membrane showed that the section was perpendicular to the BM surface.
Mesangial volume fraction, $\mathrm{V}_{\mathrm{v}}$ (mes/glom), was estimated by point counting (an 8: 1-grid) using the circumscribed polygon as reference space [10]. Mesangial matrix was estimated as volume fraction of mesangium, $\mathrm{V}_{\mathrm{v}}$ (mat/mes), using a 2: 1-grid. The product of the two volume fractions gives matrix as fraction of glomerular space, $\mathrm{V}_{\mathrm{V}}$ (matrix/glom). Matrix star volume was obtained by measuring linear intercepts in the matrix, from random points within matrix, in a direction with a 3-dimensional uniform orientation distribution [18]. The point-sampled intercepts $\left(l_{0}\right)$ were classified with a ruler. The matrix star-volume, $V^{*}=(\pi / 3) \cdot\left(1_{0}{ }^{3}\right)$. The star volume is proportional with confluence and/or convexity of the matrix. Increasing star volume implies a high degree of separation of mesangial cells and their segments. Matrix-thickness, matrix-T, was estimated as the ratio of $\mathrm{V}_{\mathrm{V}}$ (matrix/tuft)/S $\mathrm{S}_{\mathrm{v}}$ (mesangial-urinary surface/tuft).

\section{Statistical analysis}

Comparisons between the two subsets of patients, on CSII or CT, respectively, were done by unpaired, Student's $t$-test, changes over time by paired Student's $t$-test, and linear correlations were tested by least squares regression to the mean (Number Cruncher Statistical System, Kaysville, Utah, USA). The a priori hypotheses were that CSII would lead to improved blood glucose control and would lessen the expected progression of morphological lesions. Therefore, one-sided tests were used. As for the relationship between AER level and morphological lesions, the a priori hypothesis was that higher AER is associated with more advanced lesions. Therefore correlations between AER and morphology were tested one-sided. AER-values were logarithmically transformed before statistical analysis and then antiloged. Results are presented as mean with $95 \%$ CI. Statistical significance was accepted with $p$-values less than $5 \%$.

Since the idea in this study was not to test the efficacy of insulin pumps vs multiple injections, but rather to test the effect of improved metabolic control, all patients were considered together in correlation analyses of change in structural parameters vs $\mathrm{HbA}_{1 \mathrm{c}}$ during the study.

\section{Results}

The patients on intensified treatment (CSII) improved their $\mathrm{HbA}_{1 \mathrm{c}}$ from $10.1 \%(8.9-11.3 \%)$ at entry to $8.6 \%$ (7.9-9.2) at the end of the study $(p=0.01)$. No significant reduction, $10.1 \%(8.3-11.9 \%)$ vs $9.7 \%$ (8.7$10.8 \%$ ), was observed in the CT-group. The mean $\mathrm{HbA}_{1 \mathrm{c}}$ (nine measurements per patient) during the study period, was lower in the CSII-group than in the CT-group, $8.7 \%(8.1-9.3)$ vs $9.9 \%(8.5-11.3), p=0.04$.

The development of the structural changes is presented in Table 2. The CSII-group showed a significant increase during the study only for BM thickness, whereas the CT-group increased in BMT, matrix/mesangial volume fraction, and matrix star volume. The increase in BMT (Fig. 2) and matrix/mesangial volume fraction was significantly higher in the CT- than in the CSII-group, whereas the difference in matrix/glomerular volume fraction ( $p=0.051)$ and matrix star volume $(p=0.11)$ did not reach statistical significance. Neither group showed any change in mesangial/glomerular volume fraction. 
Table 2. Structural parameters in 18 IDDM patients on CSII or CT. Results at baseline (B) and follow-up (F) after 26-34 months

\begin{tabular}{|c|c|c|c|c|c|c|c|c|c|c|c|c|}
\hline \multirow[t]{2}{*}{$\begin{array}{l}\text { Subject } \\
\text { no }\end{array}$} & \multicolumn{2}{|c|}{$\begin{array}{l}\text { Basement membrane } \\
\text { thickness (nm) }\end{array}$} & \multicolumn{2}{|c|}{$\begin{array}{l}\text { Matrix/mesangial } \\
\text { volume fraction }\end{array}$} & \multicolumn{2}{|c|}{$\begin{array}{l}\text { Matrix/glomerular } \\
\text { volume fraction } \\
\end{array}$} & \multicolumn{2}{|c|}{$\begin{array}{l}\text { Mesangial/glomerular } \\
\text { volume fraction }\end{array}$} & \multicolumn{2}{|c|}{$\begin{array}{l}\text { Matrix star } \\
\text { volume }\left(\mu \mathrm{m}^{3}\right) \\
\end{array}$} & \multicolumn{2}{|c|}{$\begin{array}{l}\text { Matrix } \\
\text { thickness }(\mu \mathrm{m})\end{array}$} \\
\hline & B & $\mathrm{F}$ & $\mathrm{B}$ & $\mathrm{F}$ & $\bar{B}$ & $F$ & B & $\mathrm{F}$ & $\bar{B}$ & $\mathrm{~F}$ & $\mathrm{~B}$ & $\mathrm{~F}$ \\
\hline $\begin{array}{l}\text { CSII } \\
1 \\
2 \\
3 \\
4 \\
5 \\
6 \\
7 \\
8 \\
9\end{array}$ & $\begin{array}{l}553 \\
602 \\
709 \\
613 \\
570 \\
780 \\
590 \\
465 \\
742\end{array}$ & $\begin{array}{l}626 \\
662 \\
813 \\
629 \\
681 \\
800 \\
589 \\
524 \\
806\end{array}$ & $\begin{array}{l}0.61 \\
0.66 \\
0.59 \\
0.53 \\
0.56 \\
0.52 \\
0.59 \\
0.60 \\
0.66\end{array}$ & $\begin{array}{l}0.61 \\
0.57 \\
0.65 \\
0.57 \\
0.57 \\
0.63 \\
0.60 \\
0.54 \\
0.55\end{array}$ & $\begin{array}{l}0.12 \\
0.15 \\
0.14 \\
0.11 \\
0.12 \\
0.15 \\
0.11 \\
0.13 \\
0.16\end{array}$ & $\begin{array}{l}0.12 \\
0.13 \\
0.14 \\
0.13 \\
0.11 \\
0.16 \\
0.11 \\
0.11 \\
0.14\end{array}$ & $\begin{array}{l}0.19 \\
0.22 \\
0.24 \\
0.21 \\
0.21 \\
0.29 \\
0.19 \\
0.22 \\
0.24\end{array}$ & $\begin{array}{l}0.19 \\
0.23 \\
0.22 \\
0.23 \\
0.20 \\
0.25 \\
0.19 \\
0.20 \\
0.26\end{array}$ & $\begin{array}{l}33 \\
23 \\
22 \\
23 \\
15 \\
31 \\
21 \\
26 \\
38\end{array}$ & $\begin{array}{l}24 \\
33 \\
39 \\
33 \\
17 \\
32 \\
14 \\
18 \\
43\end{array}$ & $\begin{array}{l}3.3 \\
2.7 \\
3.6 \\
2.1 \\
3.1 \\
3.7 \\
3.2 \\
2.3 \\
3.8\end{array}$ & $\begin{array}{l}3.1 \\
3.7 \\
4.2 \\
3.8 \\
2.7 \\
4.9 \\
3.2 \\
2.4 \\
3.7\end{array}$ \\
\hline $\begin{array}{l}\text { Mean } \\
95 \% \text { CI } \\
\text { B vs F }\end{array}$ & $\begin{array}{l}625 \\
548-702 \\
p=0.00\end{array}$ & $\begin{array}{l}681 \\
601-760\end{array}$ & $\begin{array}{l}0.59 \\
0.55-0.63 \\
\text { NS }\end{array}$ & $\begin{array}{l}0.59 \\
0.56-0.62\end{array}$ & $\begin{array}{l}0.13 \\
0.12-0.15 \\
\text { NS }\end{array}$ & $\begin{array}{l}0.13 \\
0.12-0.14\end{array}$ & $\begin{array}{l}0.22 \\
0.20-0.25 \\
\text { NS }\end{array}$ & $\begin{array}{l}0.21 \\
0.20-0.24\end{array}$ & $\begin{array}{l}26 \\
20-31 \\
\text { NS }\end{array}$ & $\begin{array}{l}28 \\
20-36\end{array}$ & $\begin{array}{l}3.1 \\
2.6-3.6 \\
\text { NS }\end{array}$ & $\begin{array}{l}3.5 \\
2.9-4.1\end{array}$ \\
\hline $\begin{array}{l}C T \\
10 \\
11 \\
12 \\
13 \\
14 \\
15 \\
16 \\
17 \\
18\end{array}$ & $\begin{array}{l}372 \\
562 \\
671 \\
647 \\
555 \\
611 \\
608 \\
516 \\
515\end{array}$ & $\begin{array}{l}524 \\
647 \\
942 \\
890 \\
830 \\
785 \\
691 \\
433 \\
574\end{array}$ & $\begin{array}{l}0.62 \\
0.59 \\
0.58 \\
0.54 \\
0.50 \\
0.63 \\
0.58 \\
0.55 \\
0.61\end{array}$ & $\begin{array}{l}0.68 \\
0.64 \\
0.65 \\
0.68 \\
0.54 \\
0.65 \\
0.63 \\
0.57 \\
0.59\end{array}$ & $\begin{array}{l}0.14 \\
0.12 \\
0.12 \\
0.14 \\
0.11 \\
0.13 \\
0.10 \\
0.13 \\
0.12\end{array}$ & $\begin{array}{l}0.14 \\
0.10 \\
0.17 \\
0.14 \\
0.12 \\
0.12 \\
0.13 \\
0.14 \\
0.13\end{array}$ & $\begin{array}{l}0.23 \\
0.21 \\
0.21 \\
0.25 \\
0.21 \\
0.20 \\
0.18 \\
0.23 \\
0.19\end{array}$ & $\begin{array}{l}0.21 \\
0.16 \\
0.26 \\
0.21 \\
0.22 \\
0.19 \\
0.20 \\
0.24 \\
0.22\end{array}$ & $\begin{array}{l}25 \\
35 \\
28 \\
43 \\
26 \\
28 \\
17 \\
23 \\
25\end{array}$ & $\begin{array}{l}28 \\
39 \\
74 \\
47 \\
21 \\
34 \\
35 \\
26 \\
30\end{array}$ & $\begin{array}{l}2.8 \\
3.6 \\
3.5 \\
3.0 \\
4.6 \\
2.6 \\
2.7 \\
2.4 \\
3.7\end{array}$ & $\begin{array}{l}2.7 \\
2.7 \\
5.9 \\
3.9 \\
3.1 \\
2.9 \\
3.3 \\
2.5 \\
2.9\end{array}$ \\
\hline $\begin{array}{l}\text { Mean } \\
95 \% \text { CI } \\
\text { B vs F }\end{array}$ & $\begin{array}{l}562 \\
493-631 \\
p=0.00\end{array}$ & $\begin{array}{l}702 \\
569-835\end{array}$ & $\begin{array}{l}0.57 \\
0.54-0.61 \\
p=0.006\end{array}$ & $\begin{array}{l}0.63 \\
0.59-0.66\end{array}$ & $\begin{array}{l}0.12 \\
0.11-0.12 \\
p=0.12\end{array}$ & $\begin{array}{l}0.13 \\
30.12-0.15 \\
\text { NS }\end{array}$ & $\begin{array}{l}0.21 \\
0.20-0.23 \\
\text { NS }\end{array}$ & $\begin{array}{l}0.21 \\
0.19-0.23\end{array}$ & $\begin{array}{l}28 \\
22-33 \\
p=0.0\end{array}$ & $\begin{array}{l}37 \\
25-49 \\
4\end{array}$ & $\begin{array}{l}3.2 \\
2.7-3.8 \\
\text { NS }\end{array}$ & $\begin{array}{l}3.3 \\
2.5-4.1\end{array}$ \\
\hline $\begin{array}{l}\text { CSII vs. } \\
\text { CT }(\Delta)\end{array}$ & $p=0.03$ & & $p=0.04$ & & $p=0.052$ & & NS & & NS & & NS & \\
\hline
\end{tabular}

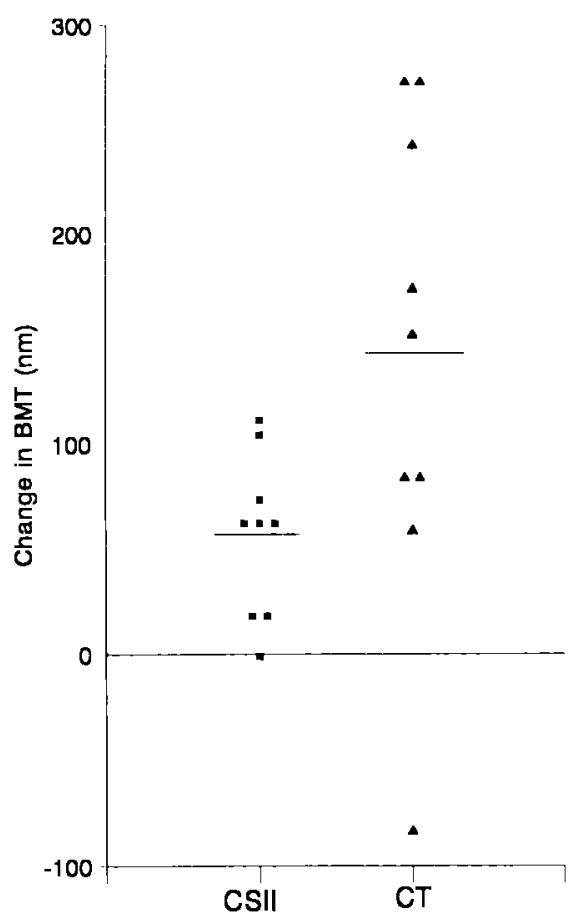

Fig. 2. Change in BMT during 26-34 months. The difference between the two groups of subjects, IDDM patients on CSII and CT respectively, is statistically significant $(p=0.03$ )
The correlation analysis between mean $\mathrm{HbA}_{1 \mathrm{c}}$ of the study period and the change $(\Delta)$ from baseline to follow-up in the structural parameters showed a strong association between mean $\mathrm{HbA}_{1 \mathrm{c}}$ and $\triangle$-BMT $(r=0.70, p=0.001$, Fig. 3). Furthermore, a positive, but not significant, correlation was found between mean $\mathrm{HbA}_{1 \mathrm{c}}$ and $\Delta$-matrix/glomerular volume fraction ( $r=0.33, p=0.09)$ and matrix/mesangial volume fraction $(r=0.26, p=0.15)$.

The AER showed a very modest increase in both groups; in the CSII-group from $27(10-75) \mu \mathrm{g} / \mathrm{min}$ to 34 $(12-98) \mu \mathrm{g} / \mathrm{min}$, and in the CT-group from $28(12-67)$ $\mu \mathrm{g} / \mathrm{min}$ to $32(12-83) \mu \mathrm{g} / \mathrm{min}$. The increase did not reach statistical significance in either group. Even though all of the patients had persistent microalbuminuria before the study, some had AER values less than $15 \mu \mathrm{g} / \mathrm{min}$ at baseline and occasionally during the study.

The correlation between AER and the respective structural parameters at the beginning of the study was: BMT ( $r=0.46, p=0.03)$, matrix/glomerular volume fraction ( $r=0.34, p=0.08, \mathrm{NS})$, matrix/mesangial volume fraction $(r=0.31, p=0.10$, NS), matrix star volume ( $r=0.12$, NS), matrix thickness $(r=0.15$, NS), and mesangial/glomerular volume fraction $(r=0.14$, NS). At the end of the study an even closer association 


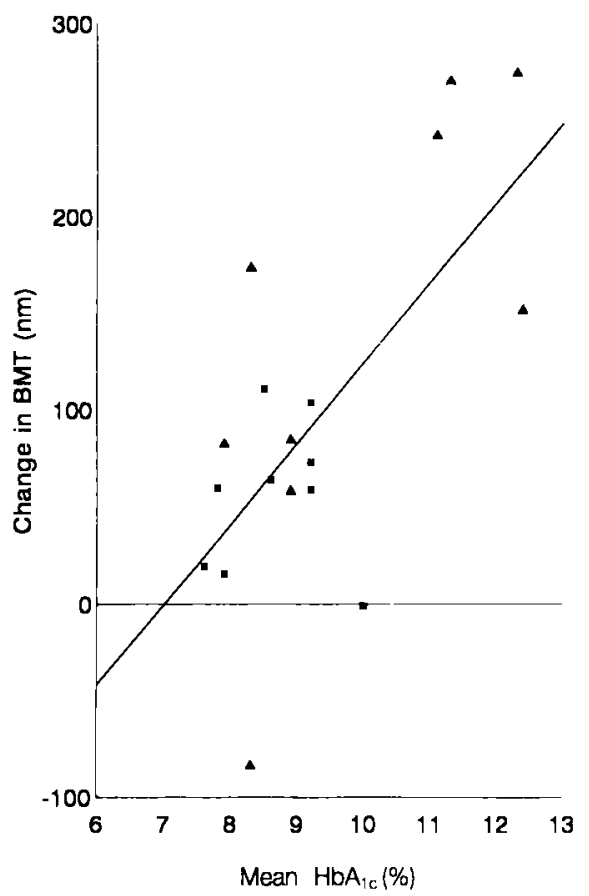

Fig.3. Change in BMT vs mean $\mathrm{HbA}_{1 \mathrm{c}}$ during 26-34 months in 18 subjects with IDDM $(r=0.70, p=0.001)$. CSII, CT

was observed: $\mathrm{BM}$ thickness $(r=0.58, p=0.006)$, matrix/glomerular volume fraction $(0.52, p=0.01)$ [Fig. 4], matrix star volume $(r=0.59, p=0.005)$, matrix thickness $(0.58, p=0.006)$, and mesangial/glomerular volume fraction $(r=0.41, p=0.04)$. Further, the changes $(\Delta)$ in structural parameters during the study, $\triangle \mathrm{BMT}(r=0.44, p=0.03), \Delta$ matrix star volume $(r=0.69, p=0.001), \Delta$ mesangial/glomerular volume fraction $(r=0.52, p=0.01), \Delta$ matrix/ glomerular volume fraction $(r=0.40, p=0.05$, NS), and $\Delta$ matrix thickness $(r=0.42, p=0.04)$ showed a positive correlation with mean AER the year preceding the study.

Blood pressure remained unchanged in both groups during the study period. $\Delta$ Systolic blood pressure was $-2.2 \mathrm{~mm} \mathrm{Hg}(-9.8-5.4)$ vs $1.3 \mathrm{~mm} \mathrm{Hg}(-5.6-8.3)$, and $\Delta$ diastolic blood pressure $2.6 \mathrm{~mm} \mathrm{Hg}(-4.0-9.1)$ vs $0.4 \mathrm{~mm} \mathrm{Hg}(-5.0-5.4)$, in the CSII- and the CT-group respectively. No correlation was found between blood pressure and change in structural parameters.

The glomerular filtration rate showed no significant change in either of the two groups (data not shown). In the two groups combined glomerular filtration rate was at baseline $143(130-156) \mathrm{ml} \cdot \mathrm{min}^{-1} \cdot\left(1.73 \mathrm{~m}^{2}\right)^{-2}$ and 150 (136-165) $\mathrm{ml} \cdot \mathrm{min}^{-1} \cdot\left(1.73 \mathrm{~m}^{2}\right)^{-2}$ at follow-up and did not correlate with BMT.

The charge selectivity index, clearances of $\left(\mathrm{IgG} / \mathrm{IgG}_{4}\right)$, was not correlated to BMT at the beginning of the study. However a negative correlation between the increase in basement membrane thickness and change in charge selectivity index was observed $(r=-0.73, p=0.001$, Fig. 5).

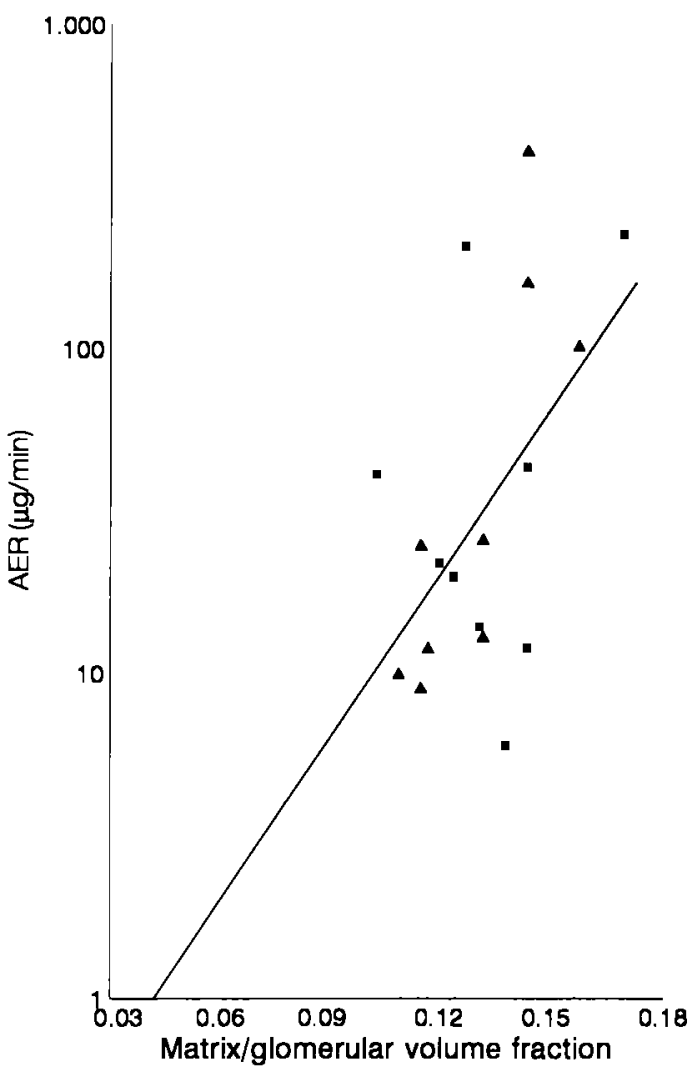

Fig.4. AER in 18 subjects with IDDM vs matrix/glomerular volume fraction at the end of the study period $(r=0.52, p=0.01)$. - CSII, $\triangle$ CT

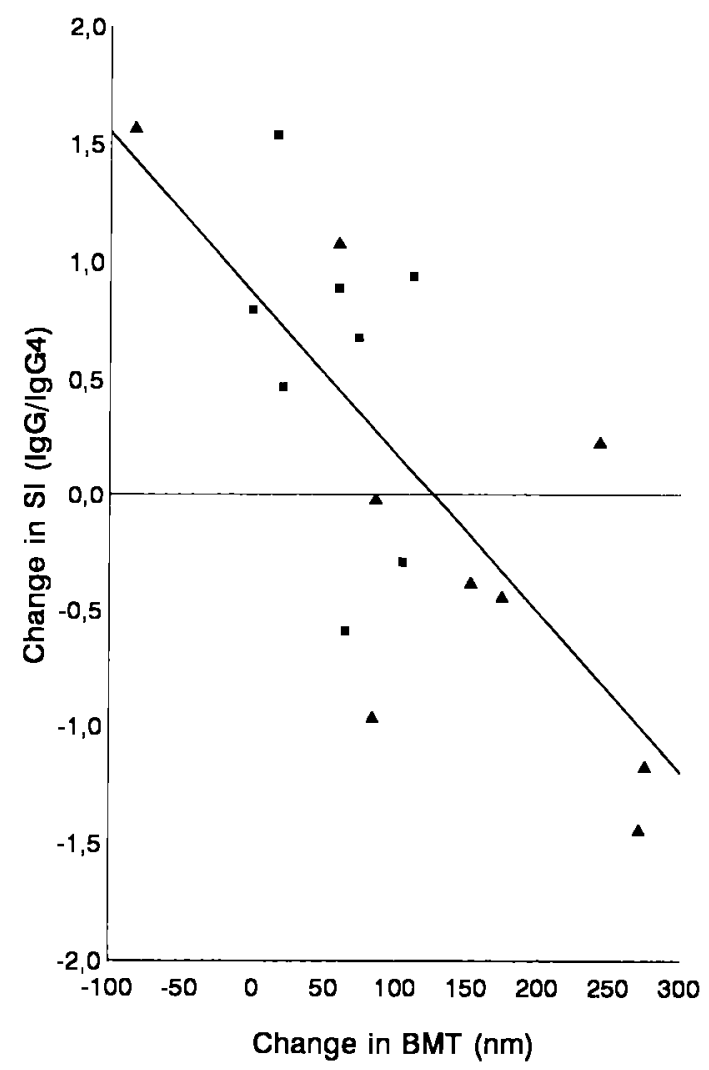

Fig.5. Change in selectivity index $\left(\mathrm{IgG} / \mathrm{IgG}_{4}\right)$ vs change in $\mathrm{BMT}$ during 26-34 months in 17 (in one of the 18 patients we did not obtain adequate urine and serum measurements of IgG and $\mathrm{IgG}_{4}$ [11]) subjects with IDDM $(r=0.73, p<0.001)$. CSII, $\triangle$ CT 


\section{Discussion}

The present randomized, prospective study shows that in IDDM patients with microalbuminuria, an increase of BMT and matrix expansion takes place during a period of 2 to 3 years. The increment is significantly larger in the group randomized to CT than in those on intensive treatment by CSII.

In the total group of patients the increment of BM thickness and matrix/glomerular volume fraction during the study showed a significant positive correlation with mean $\mathrm{HbA}_{1 \mathrm{c}}$. Hitherto, no prospective study has shown similar data in human native diabetic kidneys. Two previous reports dealt with the effect of pancreas transplantation on kidney allograft in diabetic patient $[19,20]$. One showed that normalization of blood glucose was followed by less severe glomerulopathy, i.e. less increase in BMT and mesangial volume fraction [19], and the other study that the increment of the mesangial volume fraction, but not the BM-thickening, was halted after 12 years [20]. In the cross-sectional study of our series at baseline, we found an association between $\mathrm{HbA}_{1 \mathrm{c}}$ and $\mathrm{BM}$ thickness and matrix star volume, respectively [10]. As discussed [10] a high precision in the estimates was mandatory for the study. With the use of three levels in each glomerulus the variation in mesangial estimates was considerably reduced.

It is not known which constituents are responsible for the early thickening of $\mathrm{BM}$ and matrix expansion in diabetes. In the BM collagen IV, laminin and heparansulphate proteoglycan predominate while the mesangial matrix also contains collagen $\mathrm{V}$, fibronectin, trombospondin, and chondroitin/dermatan sulphate proteoglycans [21]. Short-term experimental studies show that hyperglycaemia induces increased production of the aforementioned proteins, the main constituents of the extracellular material [22-26]. Furthermore, hyperglycaemia leads to accumulation of advanced glycated end-products of proteins. These glycated proteins do contribute to the formation of pathological tissue deposits [27].

In controlled, prospective, intervention studies with a limited number of patients, improved blood glucose control retards progression of AER [11] and reduces the risk of developing clinical nephropathy [12, 13]. The Diabetes Control and Complications Trial confirms these results in a large-scale study, even though the design of the study focused on retinopathy [28]. An association between the degree of AER and structural parameters has only been found when a "structural index", which included BMT and matrix volume fraction, was constructed [9,29]. In the present study the results were very consistent: at the end of the study, AER showed a positive correlation with all of the structural parameters. The same pattern was found at entry, but not to the same extent. The patients with the highest AER levels at the beginning of the study, showed the most marked progression in structural parameters. These relationships were observed, irrespective of the well-known, large intra-individual variation of AER [30]. It should be noted that in the last part of the the study, 4 of the 21 patients had AER-values below $15 \mu \mathrm{g} / \mathrm{min}$ in repeated urine samples and thus by definition no longer had microalbuminuria [31].

The cause of hypertension in diabetic nephropathy and the relative importance of hypertension in the early phases of diabetic nephropathy, is still controversial [32]. In the study reported by Chavers et al. [33], the structural changes in microalbuminuric patients were most pronounced in those patients who also had either elevated blood pressure or reduced glomerular filtration rate, a category that is not represented in our series. We found no correlation between blood pressure and the changes in structure, but the blood pressure was within normal limits and the range was rather narrow. This may indicate that blood pressure at this early stage of nephropathy does not play a major role in the initiation of the early structural lesions.

The long-term prognosis in diabetic nephropathy is linked to loss of capillary surface in the advanced stages. Thickening of the peripheral BM, as well as expansion of mesangial regions, in particular the matrix, are integral elements in the pathological picture at this stage. Our studies have shown again that the thickening of peripheral BM and the mesangial matrix expansion seem to develop in parallel. We observed a striking correlation between the increment of $\mathrm{BM}$ thickness and loss of negative charge, as investigated by the selectivity index, clearances of $\left(\mathrm{IgG} / \mathrm{IgG}_{4}\right)$, indicating that the thickened $\mathrm{BM}$ is likely to be qualitatively changed. Thus, loss of anionic charge may be an early event in the development of diabetic nephropathy, as suggested by Deckert et al. [16], and may be explained by decreased sulphatation of heparan sulphate proteoglycan in the glomerular basement membrane. This process is also hampered in the matrix and it is proposed that this abnormality contributes to the development of diabetic glomerulopathy [24].

We have shown that improved blood glucose control retards the development of structural changes in early diabetic nephropathy. This is found, even with a modest improvement in $\mathrm{HbA}_{1 \mathrm{c}}$ and without achieving optimal blood glucose control. An $\mathrm{HbA}_{1 \mathrm{c}}$-level below 7.5$8.0 \%$ is probably sufficient to avoid progression of urinary albumin excretion [34]. Blood glucose values corresponding to this level can be achieved without an increased risk of serious hypoglycaemia $[35,36]$. Furthermore, the relationship between AER and structural parameters, gives additional support to the clinical importance of detecting elevated albumin excretion in the early stage of diabetic nephropathy when intervention is still potentially beneficial. 
Acknowledgements. We thank Ms. K.Gerlach, Ms. B. Saugbjerg, Ms. J. Arve, and Ms. L. Lysgaard for skillful technical assistance, and Ms. B. Tyrdal for excellent typing. The kidney biopsies were taken by Dr. J. A. Jakobsen and Dr. T. S. Egge at the Department of Radiology, Rikshospitalet, Oslo, Norway. The study was supported by grants from the following: Norwegian Diabetes Association, Aker Diabetes Research Foundation, Jahre's Research Foundation, Norwegian Medical Research Council (NAVF), Odd Fellows Medical Foundation, Novo-Nordisk Pharma, Norwegian Hoechst A/S, Juvenile Diabetes Foundation Int., grant \#190592, The Danish Diabetes Association, The Danish Medical Research Council, Lægevidenskabens Fremme, Bernhard and Marie Klein's Legat, Ruth IE Konig-Petersens's Fond, NOVO Foundation, Århus University Research Foundation.

\section{References}

1. Pirart J (1978) Diabetes mellitus and its degenerative complications. A prospective study of 4400 patients observed between 1947 and 1973. Diabetes Care 1:168-188

2. Wisemann, M, Viberti GC, Mackintosh D, Jarrett RF, Keen H (1984) Glycaemia, arterial pressure and microalbuminuria in type 1 (insulin-dependent) diabetes mellitus. Diabetologia 26: $401-405$

3. Mathiesen ER, Saurbrey N, Hommel E, Parving HH (1986) Prevalence of microalbuminuria in children with type 1 (insulin-dependent) diabetes mellitus. Diabetologia 29: 640643

4. Bangstad H-J, Hanssen KF, Kierulf $P$ et al. (1987) Elevated albumin excretion rate is common among poorly controlled adolescent insulin dependent diabetics. Diabetes Res 6: 4346

5. Mortensen HB, Martinelli K, Nørgaard K et al. (1990) A nation-wide cross-sectional study of urinary albumin excretion rate, arterial blood pressure and blood glucose control in Danish children with type 1 diabetes mellitus. Diabetic Med 7:887-897

6. Joner G, Brinchmann-Hansen $\mathrm{O}$, Torres $\mathrm{CG}$, Hanssen KF (1993) A nationwide cross-sectional study of retinopathy and microalbuminuria in young Norwegian type 1 (insulin-dependent) diabetic patients. Diabetologia 35: 10491055

7. Nørgaard K, Storm B, Graae M, Feldt-Rasmussen B (1988) Elevated albumin excretion and retinal changes in children with type 1 diabetes are related to long-term poor blood glucose control. Diabetic Med 6: 325-328

8. Bangstad H-J, Hanssen KF, Dahl-Jørgensen K, Aagenæs $\emptyset$ (1989) Microalbuminuria is associated with long term poor glycemic control in adolescent insulin dependent diabetics. Diabetes Res 12: 71-74

9. Walker JD, Close CF, Jones SL et al. (1992) Glomerular structure in type I (insulin-dependent) diabetic patients with normo- and microalbuminuria. Kidney Int 41: 741-748

10. Bangstad H-J, Østerby R, Dahl-Jørgensen K et al. (1993) Early glomerulopathy is present in young type 1 (insulin-dependent) diabetic patients with microalbuminuria. Diabetologia 36: 523-529

11. Dahl-Jørgensen K, Hanssen KF, Kierulf P, Bjøro T, Sandvik L, Aagenæs $\varnothing$ (1988) Reduction of urinary albumin excretion after 4 years of continuous subcutaneous insulin-infusion in insulin-dependent diabetes mellitus. The Oslo study. Acta Endocrinol 117: 19-25

12. Feldt-Rasmussen B, Mathiesen ER, Deckert T (1986) Effect of 2 years of strict metabolic control on progression of inci- pient nephropathy in insulin-dependent diabetes. Lancet I: 1300-1304

13. Reichard P, Nilsson B-Y, Rosenquist U (1993) The effect of long-term intensified insulin treatment on the development of microvascular complications of diabetes mellitus. N Engl J Med 329: 304-309

14. Eshøj O, Feldt-Rasmussen B, Larsen ML, Mogensen CE (1987) Comparison of overnight, morning and 24-hour collections in the assesment of diabetic microalbuminuria. Diabetic Med 4: 531-533

15. Bangstad H-J, Kofoed-Enevoldsen A, Dahl-Jørgensen K, Hanssen KF (1992) Glomerular charge selectivity and the influence of improved blood glucose control in type 1 (insulindependent) diabetic patients with microalbuminuria. Diabetologia 35: 1165-1169

16. Deckert T, Feldt-Rasmussen B, Djurup R, Deckert M (1988) Glomerular size and charge selectivity in insulin-dependent diabetes mellitus. Kidney Int 33: 100-106

17. Østerby R (1973) Morphometric studies of the peripheral glomerular basement membrane in early juvenile diabetes II. Topography of the initial lesions. Diabetologia 9: 108-114

18. Gundersen HJG, Bendtsen TF, Korbo L et al. (1988) Some new, simple and efficient sterological methods and their use in pathological research and diagnosis. APMIS 96: 379394

19. Bilous RW, Mauer SM, Sutherland DER, Najarian JS, Goetz FC, Steffes MW (1989) The effect of transplantation on the glomerular structure of renal allografts in patients with insulin-dependent diabetes. $N$ Engl J Med 321: 80-85

20. Barbosa J, Steffes M, Connett J, Mauer M (1992) Hyperglycemia is causally related to diabetic renal lesions. Diabetes 41: 9 (Abstract)

21. Silbiger S, Crowley S, Shan Z, Brownlee M, Satriano J, Schlondorff D (1993) Nonenzymatic glycation of mesangial matrix and prolonged exposure of mesangial matrix to elevated glucose reduces collagen synthesis and proteoglycan charge. Kidney Int 43: 853-864

22. Brownlee M, Spiro RG (1979) Glomerular basement membrane metabolism in the diabetic rat: in vivo studies. Diabetes 28: 121-125

23. Ledbetter S, Copeland EJ, Noonan D, Vogeli G, Hassel JR (1990) Altered steady-state mRNA levels of basement membrane proteins in diabetic mouse kidneys and thromboxane synthase inhibition. Diabetes 39: 196-203

24. Cagliero E, Roth T, Roy S, Lorenzi M (1991) Characteristics and mechanisms of high-glucose-induced overexpression of basement membrane components in cultured human endothelial cells. Diabetes 40: 102-110

25. Roy S, Sala R, Cagliero E, Lorenzi M (1990) Overexpression of fibronectin induced by diabetes or high glucose: phenomenon with a memory. Proc Natl Acad Sci USA 87: 404-408

26. Poulson R, Kurkinen M, Prockop DJ, Boot-Handford RP (1988) Increased steady-state levels of laminin B1 mRNA in kidneys of long term streptozotozin-diabetic rats. J Biol Chem 263: 1072-1076

27. Brownlee M, Vlassara H, Cerami A (1984) Nonenzymatic glycosylation and the pathogenesis of diabetic complications. Ann Int Med 101: 527-537

28. The Diabetes Control and Complications Trial research group (1993) The effect of intensive treatment of diabetes on the development and progression of long-term complications in insulin-dependent diabetes mellitus. $\mathbf{N}$ Engl J Med 329: 977-986

29. Østerby R (1992) Glomerular structural changes in type 1 (insulin-dependent) diabetes mellitus: causes, consequences and prevention. Diabetologia 35: 803-812 
30. Feldt-Rasmussen B, Mathiesen ER (1984) Variability of urinary albumin excretion in incipient diabetic nephropathy. Diabetic Nephropathy 3: 101-103

31. Mogensen CE, Chachati A, Christensen CK et al. (1986) Microalbuminuria: an early marker of renal involvement in diabetes. Uremia Invest 9: 85-95

32. Mogensen CE, Hansen KW (1992) Blood pressure elevation versus abnormal albuminuria in the genesis and prediction of renal disease in diabetes. Diabetes Care 15: 1192-1204

33. Chavers BM, Bilous RW, Ellis EN, Steffes MW, Mauer SM (1989) Glomerular lesions and urinary albumin excretion in type 1 diabetes without overt proteinuria. N Engl J Med 320: 966-970
34. Dahl-Jørgensen K, Bjøro T, Kierulf P, Sandvik L, Bangstad H-J, Hanssen KF (1992) Long-term glycemic control and kidney function in insulin-dependent diabetes mellitus. Kidney Int 41: 920-923

35. Dahl-Jørgensen K, Brinchmann-Hansen O, Hanssen KF et al. (1986) Effect of near normoglycaemia for two years on progression of early diabetic retinopathy, nephropathy, and neuropathy: the Oslo study. BMJ 293: 1195-1199

36. Chantelau E, Spraul M, Mühlhauser I, Gause R, Berger M (1989) Long-term safety, efficacy and side-effects of continuous subcutaneous insulin infusion treatment for type 1 (insulin-dependent) diabetes mellitus: a one centre experience. Diabetologia 32: 421-426 